\title{
THE ROLE OF PPN1 AND PPX1 POLYPHOSPHATASES IN THE STRESS-INDUCED CHANGES OF THE POLYSACCHARIDE COMPOSITION OF CELL WALL AND EXTRACELLULAR MATRIX OF SACCHAROMYCES CEREVISIAE CELLS
}

\author{
S.I. Voychuk, O.M. Gromozova \\ Zabolotny Institute of Microbiology and Virology, NAS of Ukraine, \\ 154 Akad. Zabolotny Str., Kyiv, 03143, Ukraine \\ e-mail:svoychuk@hotmail.com
}

\begin{abstract}
Polysaccharides (PS) are important structural elements of all living organisms. They perform many important functions and protect cells from the action of various stresses. The in vivo synthesis of PS is an energy-consuming process that requires phosphates, as well as the structure of PS requires the phosphates and polyphosphates $(p o l y(P))$ as binding elements. However, the role of enzymes that metabolize poly $(P)$ (polyphosphatases, poly(P)ases) in the processes of cell wall components and extracellular matrix synthesis is poorly understood. Aim. The aim was to study the role of PPN1 and PPX1 poly(P)ases in the processes of cell wall and extracellular matrix formation. Methods. Saccharomyces cerevisiae yeast

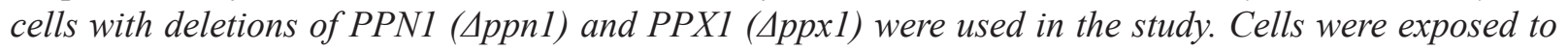
hydrogen peroxide $(25-100 \mathrm{mM})$, acetic acid $(25-100 \mathrm{mM})$ and sorbitol $(0.25-1.0 \mathrm{M})$ to induce stress reactions. $R F-E M F(40.68 \mathrm{MHz}, 15 \mathrm{~W}$ power, $30 \mathrm{~min})$ was applied separately and 30 min before treatment with other stress factors to induce an adaptive response. The influence of stress factors was evaluated by changes in the content of sugars. The sugars and sugar residues in the cell walls and extracellular matrix of the yeast cells were detected using GC/MS and lectin-gold binding test. The content of D-mannose/Dglucose (Man/Glu), D-galactose (Gal), N-acetylglucosamine (GlcNAc), N-acetylgalactosamine (GalNAc) and N-acetylneuraminic acid (NANA) was assessed. Results. The deficiency of PPN1 and PPX1 affect the content of sugars in the cell walls and extracellular matrix. The amounts of glucosamine (according to GC/MS analysis) decreased in 3-5 times in the cell walls of PPN1 and PPXI deficient cells. The lectingold test showed that the Man/Glu content was the most stable (27-38\%) among all the yeast cells, while the amounts of other sugars varied significantly. The deletion of poly (P)ases had different effects on the content of sugars in the cell walls and extracellular matrix: the extracellular matrix showed a significant decrease in GlcNAc, GalNAc and an increase in NANA, while the content of GalNAc in the cell walls remained almost constant, and the content of NANA decreased in case of PPN1 deletion and increased in case of PPX1 deletion. Correlation analysis showed a potentially high (up to 97\%) correlation between Man/Glu, GlcNAc, and GalNAc amount in cell walls, and cell viability (stress-resistance). However, only one of these sugars, GlcNAc, showed correlation with deficiency of PPN1 and PPX1. The differences between the effects observed in cells with single and double deletions of poly $(P)$ ases indicate that both enzymes positively regulate GlcNAc biosynthesis of cell walls and extracellular matrix and the biosynthesis of extracellular GalNAc. Conclusions. Both poly(P)ases (PPN1 and PPX1) are involved in the assembly of the cell wall and extracellular matrix and influence mainly the content of their minor constituents: Gal, GalNAc, GlcNAc, and NANA. The change in stresses resistance of PPN1 and PPXI deficient cells correlate with the content of Man/Glu, GalNAc and GlcNAc, which is regulated by both poly(P)ases. The marked differences and changes in the content of the PS may indicate a decrease of the cell wall rigidity and a decrease of the GPI-bound proteins portion in it, as well as the conformational changes of the PS in the extracellular matrix that resulted from the deletion of the poly $(P)$ ases.
\end{abstract}

Keywords: polysaccharides, cell wall, extracellular matrix, polyphosphatases, stresses, Saccharomyces cerevisiae. 
The yeast cell wall is a complex structure which along with various structural elements contains enzymes, adhesion factors, transport proteins, and a lot of other elements as well. The main structural elements of the cell wall are polysaccharides, which represented mainly with mannan and glucan and lesser with chitin, which in turn are associated with proteins that perform numerous functions [1]. Besides, yeast cell walls contain polyphosphate (poly $(\mathrm{P}))$ chains, which amounts to $20 \%$ of the total poly $(\mathrm{P})$ pool in the cell [2]. It is suggested that poly $(\mathrm{P})$ support a negative charge on the cell surface, play an important role in the degradation of hydrocarbons and participate in the formation of some structural elements, such as cell wall canals [3]. Despite such an important role of poly $(\mathrm{P})$ in the cell wall, no poly $(\mathrm{P})$ ase activity was shown in it. PPX1 activity was detected only in the cytoplasmic membrane and it was suggested that it might be involved in mannan synthesis [2]. However it was not shown direct involvement of poly(P)ases in the synthesis of cell wall components [1], the activity of PPX1 significantly increase in case of disruption of cell wall structure [4], which is indirectly linked due to changes in the cell.

Cell wall performs many functions, including the function of protection and counteraction of the influence of environmental factors [1]. The link between poly $(\mathrm{P})$ ase activity and cell resistance to various stress factors was established. Inactivation of poly $(\mathrm{P})$ ases cause elongation of poly $(\mathrm{P})$-chains (within cell walls as well) or decrease of exopoly(P)ase activity alone; this entails many biological effects including changes in stress response, signaling and regulatory functions, viability and proliferative activity, virulence, genome instability, and some others [5]. The models explaining the participation of poly $(\mathrm{P})$ in various life processes were proposed. However, deficiency of poly(P)ases (PPN1 or PPX1), although affecting cell resistance to stress factors, is not lethal and does not prevent the formation of the cell wall and extracellular matrix. Nothing is known about the impact of poly(P)ases on the structural and/or functional organization of various cellular organelles and structural units such as cell wall, membranes, vacuoles, mitochondria, ER, nucleus, cytoskeleton and so on. There is only some evidence that poly $(\mathrm{P})$ can activate cell wall enzymes like glucan transferase Bgl2p and maybe other glycolytic enzymes too, inducing cell wall autolysis [6]. It was suggested that the structural proteins of the cell wall and the enzymes involved in their biosynthesis are mostly not vital, since the cell can successfully compensate such deletions by enhancing the synthesis of other structural elements, such as chitin [7]. However, such assumptions are usually made under optimal conditions while many structural elements of cell (including its genetic and biochemical properties) serve to ensure cell functionality in the environment that is far from optimal. The biological functions that perform poly(P)ases PPN1 and PPX1 are probably even more important for cell resistance to the action of the stress factors [8].

A detailed study of the changes that occur in the cell walls and extracellular matrix in case of deletion of poly $(\mathrm{P})$ ases will help to understand the biological role of these enzymes in the assembling of cell wall structure and to find links between the resistance of yeast cells to the action of physical and chemical factors, changes in gene expression, changes in adhesive properties and virulence, changes in physiological and biochemical properties and, accordingly, changes in sensitivity to antibiotics, and so on. Therefore, the aim of the current work was to study the role of poly(P)ases PPN1 and PPX1 in the processes of assembly of cell wall and extracellular matrix.

\section{Materials and methods \\ Yeast strains and cultivation}

Saccharomyces cerevisiae yeast deficient in ppn 1 and $p p x 1$ (a wild type (Wt-cells), two single mutants ( $\Delta p p n 1$-cells and $\Delta p p x 1$-cells) and a double mutant ( $\Delta$ ppn $1: \because \Delta p p x 1$-cells)) were used in the study [8]. Yeasts were grown on YEPD at $28^{\circ} \mathrm{C}$ for $16 \pm 1 \mathrm{~h}$. Cells were washed from nutrient residues with PBS (pH 7.2) by centrifugation at $\times 300 \mathrm{~g}$ for $5 \mathrm{~min}$, three times, and resuspended in sterile distilled water to a concentration of $2 \times 10^{8}$ cells $/ \mathrm{ml}$ according to optical density.

\section{RF-EMF treatment}

The treatment of cells with the radiofrequency electromagnetic field (RF-EMF) was used to initialize the adaptive response processes within the cells [8]. Yeast suspensions in the polypropylene $1.5 \mathrm{ml}$ tubes were placed into the solenoid connected to the generator of EMF (40.68 MHz, $27.5 \mathrm{~V} / \mathrm{m}, 22 \mathrm{~A} / \mathrm{m}$, the capacity of radiation $15 \mathrm{~W}$, polarized in a horizontal plane). Cells exposure was performed under strict thermostatic conditions $\left(28^{\circ} \mathrm{C}\right)$ for $30 \mathrm{~min}$.

\section{Hypertonicity, oxidative and acidic stresses}

Yeasts were treated with hydrogen peroxide, acetic acid and sorbitol to create the conditions of oxidative, acidic and hypertonic stresses. Stock $(\times 2)$ solutions of the chemicals were prepared and were mixed with cell suspensions in a ratio of $1: 1$ 
and treated for $60 \mathrm{~min}$ at $28^{\circ} \mathrm{C}$. The final concentration of cells in the samples was $10^{8}$ cells $/ \mathrm{ml}$. After the treatment, the cells were washed three times with $\mathrm{diH}_{2} \mathrm{O}$ or PBS (centrifugation at $\times 300 \mathrm{~g}$, 2 min each time) and used for cell wall extraction and lectin-gold binding test, respectively.

\section{Cell walls isolation}

Cell walls were isolated as described [9]. In brief, cells were disrupted by vortexing at 3500 RPM (vortex MSV-3500 BioSan, Latvia) in $10 \mathrm{mM}$ Tris-HCl (pH 7.4) with glass beads $(0.5 \mathrm{~mm})$ and intensively washed in decreasing concentrations of $\mathrm{NaCl}(5 \%, 2 \%$ and $1 \%)$ and finally with $\mathrm{diH}_{2} \mathrm{O}$. The quality of disruption was checked with a microscopy examination. Cell walls were aliquoted (1 mg of wet weight) into the $1.5 \mathrm{ml}$ polypropylene tubes and stored at $-20^{\circ} \mathrm{C}$ until need.

\section{Cell walls sugar extraction and analysis with GC/MS}

Cell walls sugars were extracted using the sulfuric acid hydrolysis procedure as described [10]. Xylose $(0.3 \mathrm{mg} / \mathrm{ml})$ was used as an internal standard. The sugar content was determined by GC/MS according to [11].

Detection of sugar residues with lectin-gold binding test

Lectins, conjugated to gold nanoparticles, were used in the study. Concanavalin A (ConA) with the affinity to $D$-mannose/D-glucose (Man/ Glu) and $N$-acetylglucosamine (GlcNAc). Lectin of wheat (WGA) with the affinity to GlcNAc and $N$-acetylneuraminic acid (NANA). Lectin of soy (SBA) with the affinity to $N$-acetylgalactosamine (GalNAc) and D-galactose (Gal). Lectins of Lens culinaris (LCA) and Pisum sativum (PSA) both with the affinity to Man/Glu. Lectins of Solanum tuberosum (STA) and Phaseolus vulgaris (PHA) with the affinity to GlcNAc and GalNAc, respectively. Because lectins possess an affinity for several sugar residues, the portion of each sugar residue was determined as a sum or difference of the binding capacities of lectins with similar affinities. Thus, the quantity of Man/Glu was determined as a sum of bound lectins of LCA and PSA, and the number of their alfa forms as a difference between ConA and STA. The quantity of Gal and NANA: as the difference between SBA and PHA, and WGA and STA, respectively. The quantity of GlcNAc and GalNAc was determined directly according to the binding capacities of STA and PHA, respectively.

The number of lectins bound in the extracellular matrix surrounding the cells was determined by direct counting of gold particles at the digital images that were got with the help of the transmission electron microscope JEM-1400 (Jeol, Japan) at magnification $10 \mathrm{k}-80 \mathrm{k}$ and accelerating voltage $80 \mathrm{kV}$. The direct calculation of lectin-gold particles bound to the cell wall surfaces was not possible, because the number of bound lectins was too high. Therefore we determined that change of the optical density $\left(\mathrm{OD}_{492}\right)$ of cells after their interaction with lectins was a good measure of the number of lectins tightly bound to the cell walls. Unbound lectins were deleted by centrifugation at $300 \mathrm{~g}$. Cells were resuspended in PBS to the initial volume before $\mathrm{OD}_{492}$ measurement.

\section{Statistical analysis}

The central composite experimental design with three central points was used to evaluate the influence of the RF-EMF on the cell walls PS content and its influence on the effectiveness of other stress factors. The alpha for rotatability and alpha for orthogonality were 1.68 and 1.29, respectivelly. Hydrogen peroxide (25-100 mM), acetic acid (25-100 $\mathrm{mM}$ ) and osmotic shock (sorbitol 0.25-1.0 M) were used as independent factors. Stresses were applied $30 \mathrm{~min}$ after the RFEMF exposure. The changes in the PS quantities were detected with the lectin-gold binding test.

The central composite experimental design and all data analyses were performed with Statistica v.10 software (StatSoft Inc., 2011, www.statsoft. com). The significance of the differences between variances and average values was assessed by $F$-test. Differences were marked as significant at $p \leq 0.05$. The comparison of the strains by their sugar content was performed with Ward's method of cluster analysis using percent of disagreement as a measure of difference.

\section{Results}

Monosaccharide composition of the yeast cell walls

Glucose, mannose, glucosamine, and ribose were detected in the cell walls of yeast cells (Table 1). The prevalence of glucose and mannose over other sugars is typical for this type of microorganisms [1]. Ribose is not a common structural element of the yeast cell walls but is well represented in the complexes with RNA/DNA molecules [12]. It is possible to assume an incidental catch of ribose from the membrane-associated ribosomal fraction.

Deficiency of poly $(\mathrm{P})$ ases altered the ratio of the major sugars (mannose and glucose). A $6 \%$ increase of mannose content was shown in $\Delta p p n 1-c e l l s$ and a $2-3 \%$ increase of glucose in $\Delta p p x 1$-cells (including the double mutant cells). The glucosamine content decreased 3-5 times in 
the deficient cells and the lowest it content was in the cells with the double mutation. Ribose was not detected in $\Delta p p x l$-cells (including the double mutant cells). Marked differences showed that PPX1 mutation caused more distinctions in comparison to PPN1 deletion. However, the distinctions were not in the mannose content (as expected) because of the correlation found between PPX1 activity and mannose biosynthesis [2].

Table 1

Sugar content (\%) in the cell walls of Saccharomyces cerevisiae deficient in polyphosphatases $P P N 1$ and $P P X 1$

\begin{tabular}{|l|c|c|c|c|}
\hline Sugar & Parental & $\Delta p p n 1$ & $\Delta p p x \mathbf{1}$ & $\Delta p p x 1:: \Delta p p n 1$ \\
\hline Mannose & $46.8 \pm 1.1$ & $52.3 \pm 1.8$ & $46.1 \pm 2.1$ & $47.6 \pm 1.3$ \\
\hline Glucose & $50.4 \pm 1.7$ & $46.3 \pm 0.9$ & $53.2 \pm 0.3$ & $52.0 \pm 1.4$ \\
\hline Galactosamin & $2.1 \pm 0.2$ & $0.8 \pm 0.2$ & $0.7 \pm 0.1$ & $0.4 \pm 0.1$ \\
\hline Ribose & $0.6 \pm 0.1$ & $0.5 \pm 0.1$ & 0 & 0 \\
\hline
\end{tabular}

Difference:

L $100 \% \quad$ L

\section{The sugar residues of the yeast cell walls and extracellular matrix}

Saccharomyces cerevisiae cells do not have dense extracellular structures similar to a capsule of some microorganisms. Nevertheless, lectins binding showed that the extracellular matrix of these yeast cells may reach $2 \mathrm{mkm}$ in thickness (Fig. 1A, a). Lectins bind well with the cell wall components (Fig. 1A, b,c) that assesses sugar residues within the extracellular matrix and cell walls as well.

The analysis showed that yeast cell walls contain $D$-mannose/ $D$-glucose $(46 \%-49 \%)$, a lot of $N$-acetylglucosamine $(22 \%-25 \%)$ and $\mathrm{N}$-acetylgalactosamine (21\%-24\%) (Fig. 1B). Content of $D$-galactose and $N$-acetylneuraminic (NANA) acid was low, but better characterized the differences between cells of different strains. In particular, $D$-galactose was not found in the $\Delta p p x$ l-cells, while cell walls of other strains contained $1.3 \%-2.8 \%$ of this sugar. At the same time the deficiency of PPX1 resulted in an increase (to $2.0 \%$ ) of the NANA content. Therefore, the sugar content in the cell walls of $\Delta p p x 1$-cells had the largest differences from cells of other strains (Fig. 1B).

The number of lectins bound in the extracellular matrix (ECM) of the $W t$-cells was twice higher $\left(7.5 \mathrm{k}\right.$ units $\left./ \mathrm{mkm}^{2}\right)$ than in the cells with poly(P)ases deficiency $\left(3.2 \mathrm{k}-4.2 \mathrm{k}\right.$ units $/ \mathrm{mkm}^{2}$, the lowest numbers were found in the ECM of the cells with double mutation). The content of sugars in the ECM varied depending on the strain and the ECM of $\Delta p p x$ 1-cells was less different (27\%) from $W t$ cells. The PPN1 deficiency resulted in a decrease in the content of $N$-acetylglucosamine (4-6\% against $35 \%$ in the ECM of $W t$-cells) and increased content of NANA (31\% vs. $1 \%$ of $W t$-cells) (Fig. 1B).

Among all sugars, the content of $a-D$-mannose $/ a-D$-glucose and $D$-galactose $/ N$-acetylgalactosamine achieved their maximum and minimum values (respectively) in the cells of the double mutant. Such a result is the most interesting since it indicates that there are some common to both poly $(\mathrm{P})$ ases processes in the ECM assembling.

Change of sugar content in the cell walls and extracellular matrix of the PPN1 and PPX1 deficient cells under the action of stresses

Under the action of stresses, the overall amount of sugar residues identified in the cell walls remained relatively stable (the coefficient of variation for the cells of all tested strains was in the range of $6-8 \%$ ). This was due to relatively weak changes in the content of the major sugar components the variability index for which was only $5-10 \%$, while the variability of minor components exceeded $40 \%$. Nevertheless, hyperosmotic and acidic stresses significantly affected the overall content of sugar residues that were determined in the cell walls of $W t$-cells: both factors showed positive dependences, linear for osmotic stress and nonlinear for acidic stress (Fig. 2). This was due to a significant influence of all stresses on the content of $D$-mannose/ $D$-glucose in $W t$-cells, and hydrogen peroxide affected $N$-acetylglucosamine (GlcNAc) and $N$-acetylgalactosamine (GalNAc) as well. 
A
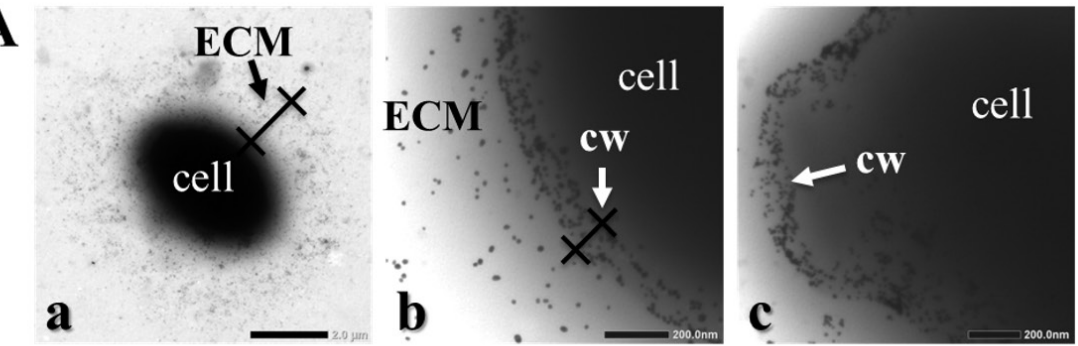

B Cell wall
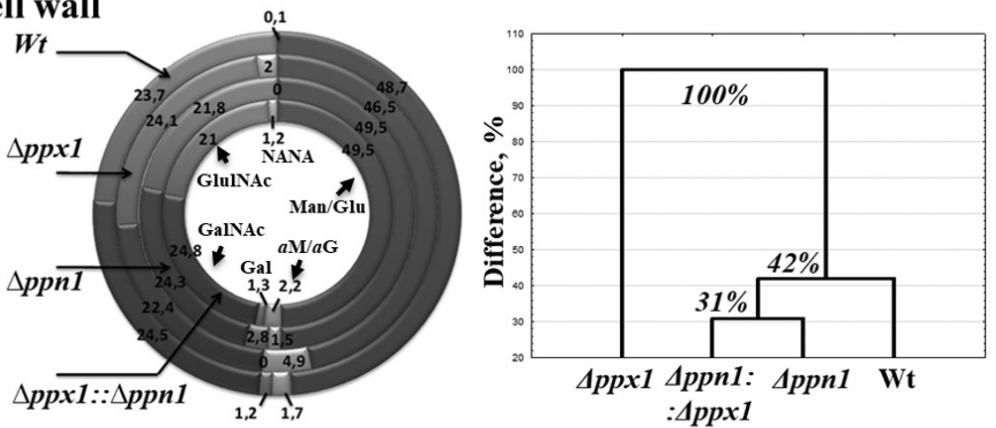

Extracellular matrix
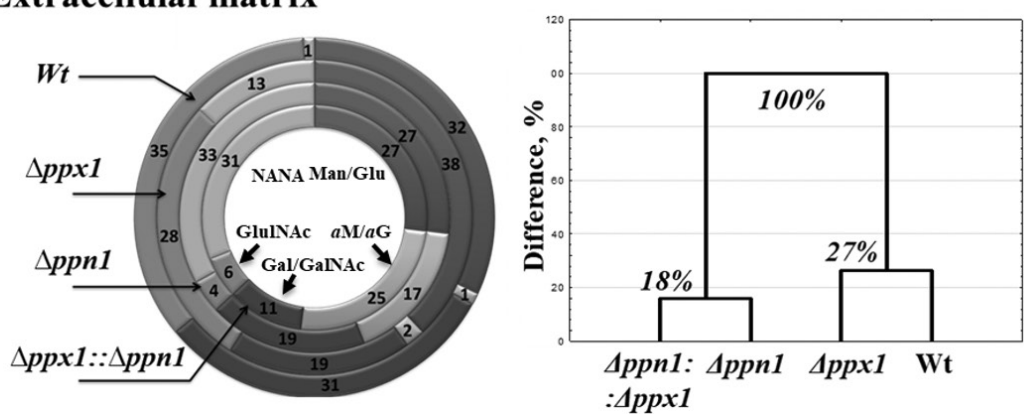

$\square$-mannose $/ D$-glucose

$\square$-galactose

$\square \mathrm{N}$-acetyl- $D$-glucosamine

$\square$ - $D$-mannose/ $\alpha$ - $D$-glucose

$\mathrm{N}$-acetyl- $D$-galactosamine

$\square N$-acetylneuraminic acid

F i g. 1. Binding of lectins with sugar residues in the cell walls and extracellular matrix of yeast cells deficient in PPN1 and PPX1. (A) Electron microscopy images showing binding of Lens culinaris lectin (LCA) labeled with colloidal gold (small 10-12 nm black dots on the images) with the $D$-mannose/ $D$-glucose (Man/Glu): (a) - a yeast cell surrounded by a layer of lectin-gold particles bound in the extracellular matrix (ECM), (b) - a fragment of a cell showing binding of labeled LCA particles with the cell wall (CW) and ECM, and (c) - binding of LCA in the area of the bud formation. The bar is $2 \mathbf{~ m k m}$ on figure (a), and $200 \mathrm{~nm}$ in figures (b) and (c).

(B) Content of sugar residues (in \%) in the cell walls and extracellular matrix.

Stresses had not the same impact on the Man/ Glu content in the cell walls of the cells deficient in poly(P)ases. Instead, all stresses (except for RF-EMF) significantly influenced the content of their minor components (GlcNAc and GalNAc). The content of GlcNAc decreased with the stress load in the cell walls of $\Delta p p n 1$-cells and $W t$-cells and increased in the cell walls of $\Delta p p x l$-cells (Fig. 3). The content of GalNAc increased under the action of hydrogen peroxide and sorbitol in the cell walls of all cells except $\Delta p p x 1$-cells. The action of acetic acid had the opposite effect on this sugar. The changes that were marked in the cell walls of the double mutant cells were intermediate between $\Delta p p n 1$-cells and $\Delta p p x$ l-cells.

The hydrogen peroxide was shown to be able to decrease the viability of the PPN1 deficient cells whereas the PPX1-deletion increased cell resistance to all stresses that we studied [8]. The RF-EMF (40.68 MHz) exposure was able to increase cell resistance to all stresses that happened, presumably, because of the induction of the adaptive response processes in the yeast cells. In the current study, we marked no significant changes in the cell wall sugar content of irradiated cells. But we noted that irradiated cells have different sugar content 


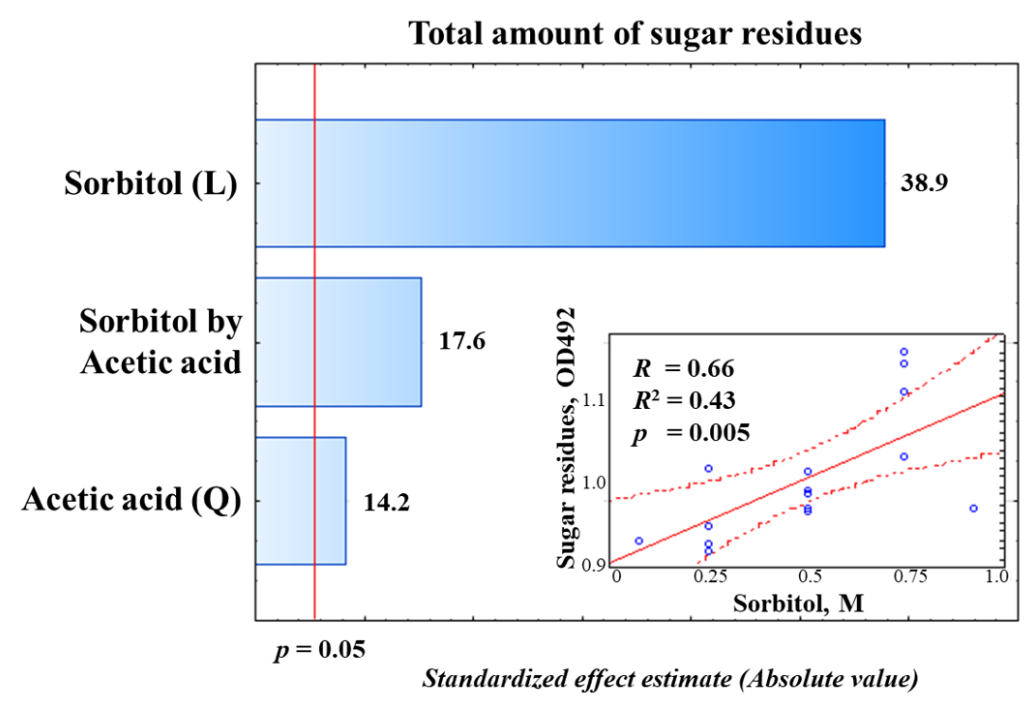

F i g. 2. Influence of stress factors on the total content of sugar residues found in the cell walls of the wild-type yeast. The inset shows a correlation between sorbitol concentration and sugars content.

$\mathbf{A}$

$W t$

GlcNAc

GalNAc

Peroxide Acetic acid Sorbitol

$\triangle P P N 1$

GlcNAc

GalNAc

$\triangle P P X 1$

GlcNAc

GalNAc

$\triangle P P N 1:: \triangle P P X 1$

GlcNAc L-/Q-

GalNAc Q+/Q-

$\mathrm{Q}+/ \mathrm{Q}-$

$\mathrm{Q}-/ \mathrm{L}+$

EMF 40.68MHz
B
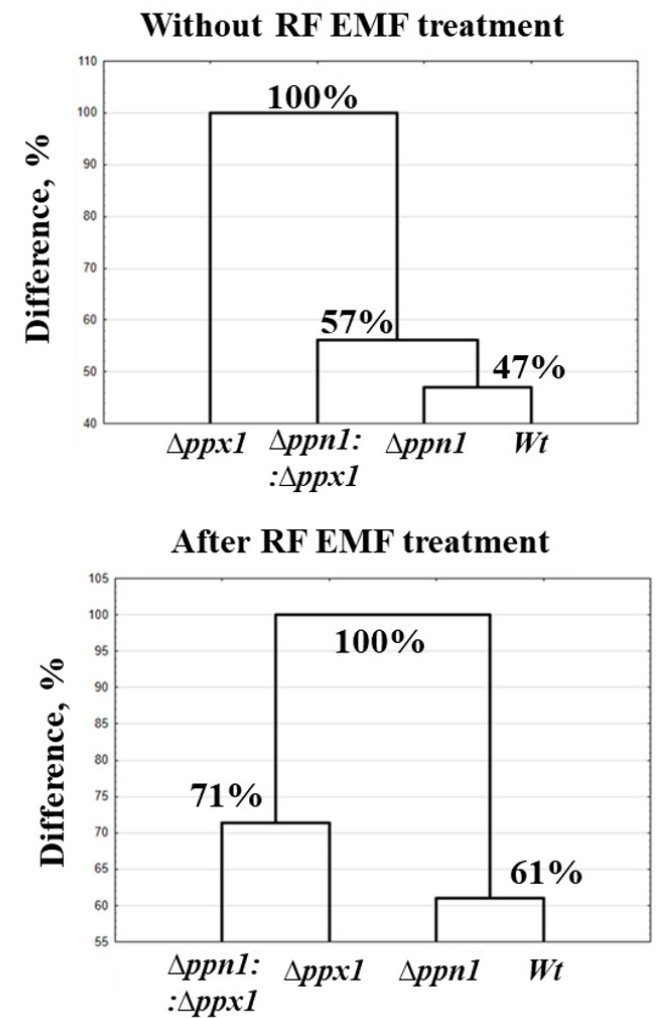

$(\mathrm{L} / \mathrm{Q})$ - linear/nonlinear dependence

(+/-) - positive/negative dependence

F i g. 3. The influence of RF-EMF on the changes of GIcNAc and GalNAc content in cell walls in response to the stress factors action. (A) The dose-effect curves. The symbol "/" separates the effects without RF-EMF pretreatment (on the left) and after RF-EMF treatment (on the right).

(B) - Impact of poly(P)ases PPN1 and PPX1 on the marked effects of RF-EMF. 
in response to other stresses in comparison to non-irradiated cells (Fig. 3). The differences in the cell wall stress response of irradiated and non-irradiated cells increased from $47 \%$ to $61 \%$ between $\Delta p p n 1$-cells and $W t$-cells, and from 57\% to $100 \%$ between the double mutant cells and $W t$-cells. The viability of the non-irradiated cells under the action of hydrogen peroxide showed high $(99 \%, p \leq 0.013)$ correlation with the content of GalNAc, while resistance to hyperosmotic stress had a $91 \%$ correlation $(p \leq 0.09)$ with the content of GlcNAc (Table 2). These correlations were not found in the irradiated cells however another potential dependence between cell resistance to hyperosmotic stress and the content of GalNAc was marked.
An additional analysis of the possible link between the content of sugars in the cell wall and extracellular matrix with the yeast viability showed no correlation with the content of sugars that was determined using GC/MS, whereas the analysis of sugars content using lectins-gold test showed high correlations (up to 99\%) between these parameters. In general, the ability of cells to survive under the influence of stress factors correlated with the content of Man/Glu in the cell walls and extracellular matrix and with the content of GalNAc and GlcNAc within the cell walls (Table 2).

\section{Table 2}

Correlations $(R, \%)$ between viability (by the colony-forming unit) [8] and sugars content in the cell walls and extracellular matrix of PPN1 and PPX1 deficient yeast cells under the action of stress factors

\begin{tabular}{|c|c|c|c|c|c|}
\hline \multirow[b]{2}{*}{ Parameter } & \multirow[b]{2}{*}{ Sugar } & \multicolumn{4}{|c|}{ Viability, colony-forming unit } \\
\hline & & $\begin{array}{c}\text { Hydrogen } \\
\text { peroxide, } \\
0.3 \mathrm{mM}\end{array}$ & $\begin{array}{c}\text { Hydrogen } \\
\text { peroxide, } \\
10 \mathrm{mM}\end{array}$ & $\begin{array}{l}\text { Acetic acid, } \\
150 \mathrm{mM}\end{array}$ & $\begin{array}{c}\text { Sorbitol, } \\
1 \mathrm{M}\end{array}$ \\
\hline \multirow{2}{*}{$\begin{array}{l}\text { Dynamical changes of cell wall } \\
\text { sugars in the non-irradiated cell }\end{array}$} & GIcNAc & 72 & 74 & 41 & $91 * * *$ \\
\hline & GalNAc & -88 & $-99 *$ & 52 & 64 \\
\hline \multirow{2}{*}{$\begin{array}{l}\text { Dynamical changes of cell wall } \\
\text { sugars in the irradiated cell }\end{array}$} & GlcNAc & -7 & -16 & -52 & 4 \\
\hline & GalNAc & 66 & 52 & 72 & $91 * * *$ \\
\hline \multirow{3}{*}{ Cell wall sugars by GC/MS } & Mannose & -39 & -73 & -56 & -52 \\
\hline & Glucose & 33 & 63 & 65 & 47 \\
\hline & Glucosamine & 19 & 30 & -22 & 15 \\
\hline \multirow{6}{*}{$\begin{array}{l}\text { Cell wall sugars by lectin-gold test } \\
\text { (mean values) }\end{array}$} & Man/Glu & $-93 * * *$ & $-95 * *$ & $-98 * *$ & $-97 * *$ \\
\hline & $a$-Man/a-Glu & 77 & 79 & $99 * *$ & 84 \\
\hline & Gal & -61 & -85 & -81 & -72 \\
\hline & GIcNAc & -78 & -56 & -38 & -68 \\
\hline & GalNAc & $91 * * *$ & $94 * *$ & 68 & $90 * * *$ \\
\hline & NANA & 44 & 55 & 83 & 56 \\
\hline \multirow{6}{*}{$\begin{array}{l}\text { Cell wall sugars by lectin-gold test } \\
\text { (median values) }\end{array}$} & Man/Glu & -85 & $-93 * * *$ & $-97 * *$ & $-92 * * *$ \\
\hline & $a$-Man/a-Glu & 54 & 18 & 49 & 46 \\
\hline & Gal & -46 & -78 & -54 & -56 \\
\hline & GlcNAc & $-90 * * *$ & -83 & $-99 *$ & $-93 * * *$ \\
\hline & GalNAc & 77 & 79 & 42 & 73 \\
\hline & NANA & 37 & 48 & 78 & 49 \\
\hline \multirow{5}{*}{$\begin{array}{l}\text { Extracellular sugars by lectin-gold } \\
\text { test (mean values) }\end{array}$} & Man/Glu & $94 * * *$ & 99* & $92 * * *$ & $98 * *$ \\
\hline & $a$-Man/a-Glu & -85 & -88 & -56 & -83 \\
\hline & GlcNAc & 68 & 86 & 48 & 70 \\
\hline & GalNAc & 40 & 44 & -04 & 34 \\
\hline & NANA & -58 & -77 & -35 & -60 \\
\hline
\end{tabular}

Legends: ${ }^{*}-p \leq 0.01, * *-p \leq 0.05, * * *-p \leq 0.10$ 
Based on the marked correlations, we can assume that the key elements that ensure cell viability are mannose/glucose, glucosamine, and galactosamine. The decrease of Man/Glu and GlcNAc in the cell walls and increase of GalNAc, as well as an increase of the Man/Glu in the extracellular matrix, resulted in the greater resistance of the yeast cells to the stresses (Fig. 4).

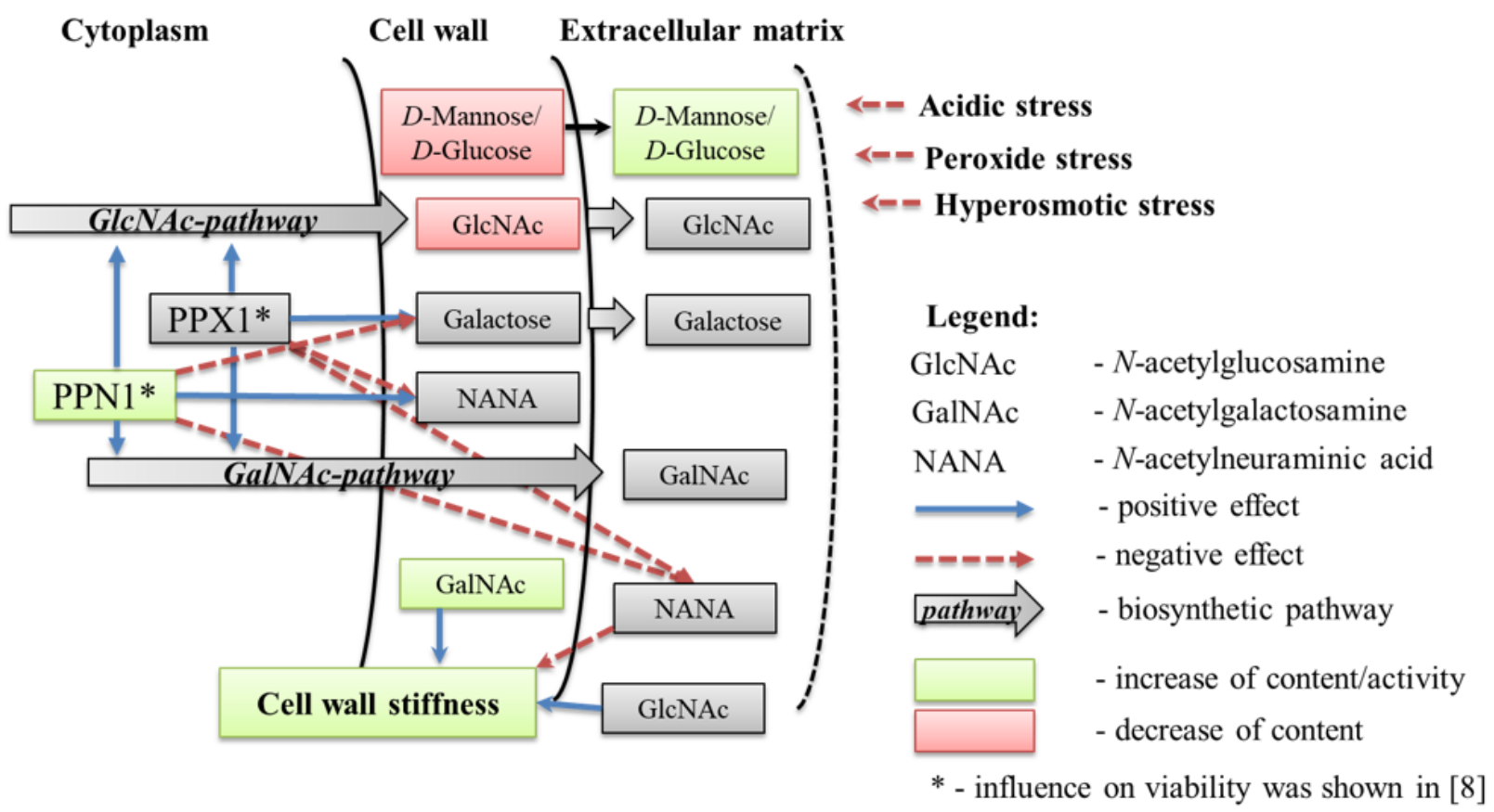

\section{F i g. 4. Scheme of the yeast cells resistance to stresses mediated by the PPN1 and PPX1 activity and by the sugar content in the cell wall and extracellular matrix}

Discussion. Both poly $(\mathrm{P})$ ases showed involvement in the process of assembly of the sugar component of the cell wall and extracellular matrix of the yeast cell. However, the deficiency of PPX1 had a stronger impact on the cell wall sugars, whereas the deficiency of PPN1 - on the sugars content in the extracellular matrix. The PPX1 is located in the cytosol and its activity was found in the vicinity to the cell wall (in the cell membrane), whereas PPN1 is located in vacuoles, nucleus, and mitochondria, and appears in the cytosol only after deletion of PPX1 and under specific growth conditions. Such localization of PPX1 may be related to the more significant contribution of its deletion to the sugar content of the cell walls. In this regard, changes that were marked in these structures in the $\Delta p p n 1$-cells can probably be considered as indirect and associated with the decrease of PPX1 activity [13].

The main components of the yeast cell walls are mannose and glucose. The decrease of glucosamine (marked with GC/MS) in the mutant cells is quite indicative because this sugar is presented as $\mathrm{N}$-acetylglucosamine (GlcNAc) in the cell wall and this is the main component of chitin. Therefore, although GlcNAc was found in minor quantities, it still has extremely important structural functions and ensures the integrity of the cell wall in case of disturbance of the cell wall structural proteins synthesis [7]. Besides, GlcNAc involved in the attachment of GPI proteins, which have a glycophosphatidylinositol (GPI) anchor at the $C$-terminus, which contains GlcNAc in its structure as well [7]. Therefore, a decrease in glucosamine can indicate a decrease in chitin content and a decrease in the content of GPI proteins, which also participate in the cell stress response [7].

In contrast to the GC/MS method, the lectin-gold binding test showed that the content of GlcNAc in the cell walls was at the level of mannose/glucose. Also, $N$-acetylgalactosamine (GalNAc), galactose (Gal) and $N$-acetylneuraminic acid (NANA) were associated with cell walls. This approach showed a link between the sugars content in the cell walls and extracellular matrix with the cell viability (that was not possible to find with results of GC/MS analysis). In addition, taking into account the specificity of the binding and arrangement 
of sugars in the polysaccharide (PS) chains, the obtained ratios of sugars may indicate the structural changes that take place in the extracellular PS (Fig. 5). Thus, the PS of the $W t$-cells is presumably composed of the long chains of mannose to which a shorter chains of glucosamine and galactosamine are bound. The poly(P)ases deficiency decreases the length of the PS chains, and the deficiency of PPX1 reduced the portion of GalNAc in the PS, whereas the PPN1 deficiency reduced the portion of GlcNAc and increased the content of GalNAc and NANA that indicate an increased branching of the PS.

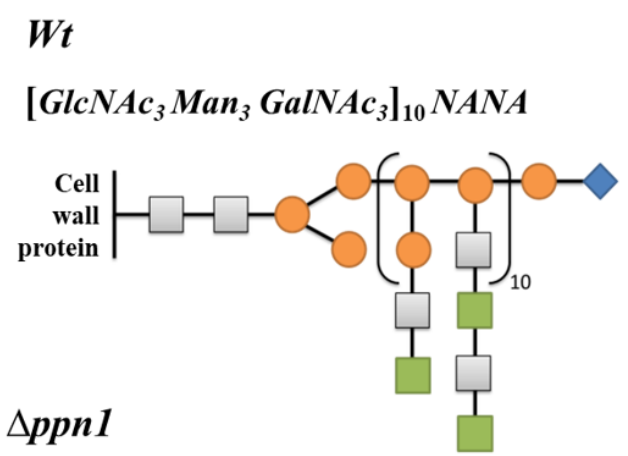

$\triangle p p x 1$

$\operatorname{GlcNAc}_{3} \mathrm{Man}_{4} \mathrm{GalNAc}_{2} \mathrm{NANA}$
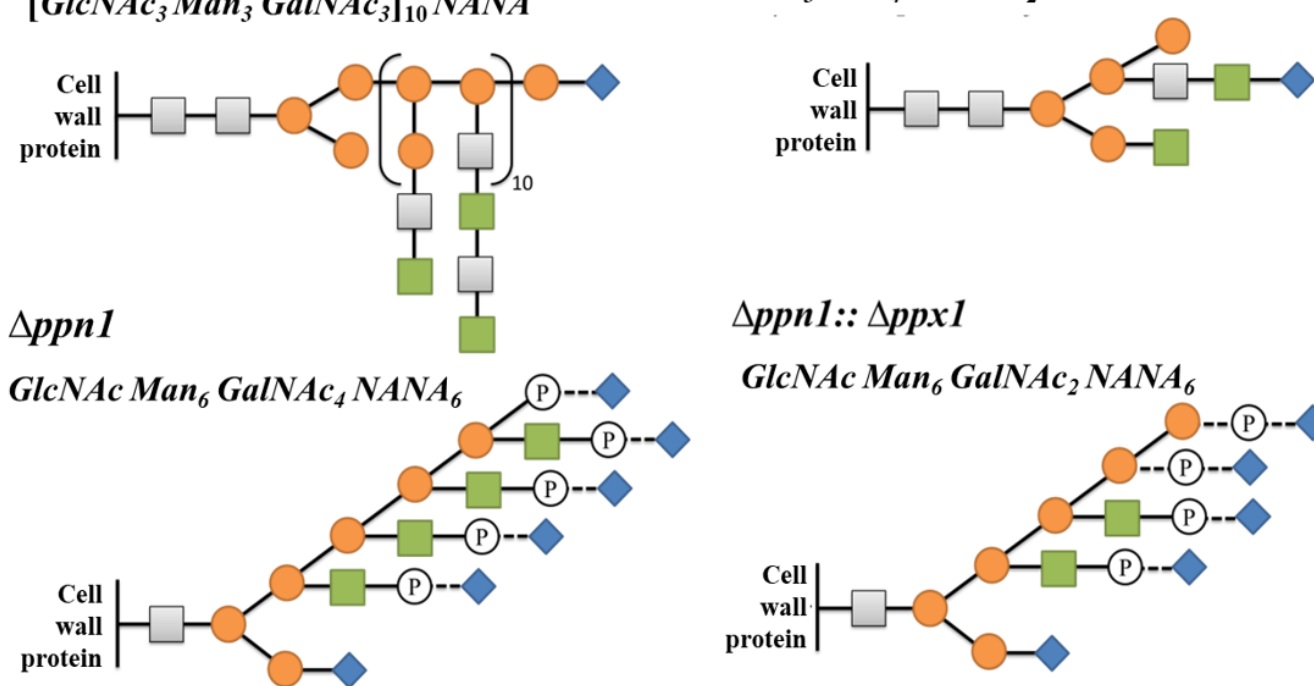

$\triangle p p n 1:: \Delta p p x 1$

GlcNAc Man $_{6}$ GaINAc $_{2} \mathrm{NANA}_{6}$

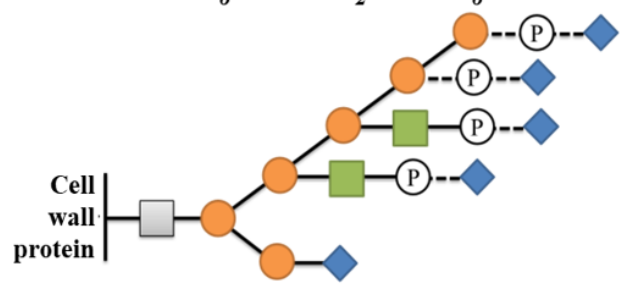

Mannose (Man)

$N$-acetylglucosamine (GlcNAc) (P) Phosphate

$N$-acetylneuraminic acid (NANA)

$\mathrm{N}$-acetylgalactosamine (GalNAc)

--- Hypothetical link

F i g. 5. The structural formula and the corresponding hypothetical structures of the polysaccharides in the extracellular matrix of yeast cells deficient in PPN1 and PPX1

Galactose, $N$-acetylgalactosamine, and $N$-acetylneuraminic acid are not typical elements of Saccharomyces cerevisiae cell walls. However, the presence of galactose is quite expectable considering that yeast has the UDP-galactose transport protein complex and the minor amounts of galactose were found in the study of fraction of 1,6-glucan isolated from the yeast cell [14]. The PPX1 presumably plays an important role in the supply of cell walls with $D$-galactose since this sugar was not found in the $\Delta p p x l$-cells.

The content of $N$-acetylneuraminic acid in the $W t$-cells was low, but it was in excess in $\Delta p p n 1$ cells and cells with the double mutation. An excess of NANA found on the surface of Candida yeast was associated with their pathogenicity [15] and thus, its high content in the extracellular matrix may indicate potential pathogenicity of the yeast cell against the mammalian cells. The PPN1 may be responsible for the regulation of the content of this sugar in the cell walls and extracellular matrix, because this sugar was not detected in the cell walls and, at the same time, was in access (to $31 \%$ ) in the extracellular matrix of $\Delta p p n 1$-cells.

The impact of both poly $(\mathrm{P})$ ases was minimal in case of the major constituents such as mannose/ glucose, however, both enzymes have a positive effect on GlcNAc, the content of which significantly reduced in case of deletion of either of these two enzymes and was minimal in the double mutant cells. Content of GlcNAc, along with GalNAc and mannose/glucose showed a correlation with the viability of yeast cells under the action of stresses. Also, the ratio of GlcNAc, GalNAc, and NANA seem to ensure the mechanical and physical properties (stiffness) of cell walls (data not shown) and, thus, ensure the resistance of cells to the action of stresses. 
Conclusions. The deletion of poly(P)ase PPN1 or PPX1 influences the content of sugars in the cell wall and extracellular matrix of yeast cells. The content of individual sugars correlates with the viability of yeast cells under the action of stress

\section{РОЛЬ ПОЛІФОСФАТАЗ РРN1 І РРХ1 У СТРЕС-ІНДУКОВАНИХ ЗМІНАХ ПОЛІСАХАРИДНОГО СКЛАДУ КЛІТИННОЇ СТІНКИ І ПОЗАКЛІ- ТИННОГО МАТРИКСУ КЛІТИН SACCHAROMYCES CEREVISIAE}

\section{С.I. Войчук, О.М. Громозова}

Інститут мікробіології і вірусологї ім. Д.К. Заболотного НАН Украӥни, вул. Академіка Заболотного, 154, Київ, 03143, Україна

\section{Резюме}

Полісахариди (ПС) є важливими структурними елементами всіх живих організмів. Вони виконують низку важливих функцій і захищають клітини від дії різних факторів стресу. Синтез ПС $\epsilon$ енергозатратним процесом, який потребує фосфатів, так само й структура ПС потребує участі фосфатів і поліфосфатів (poly(P)) як зв'язуючих елементів. Проте роль ферментів метаболізму poly(Р) (поліфосфатаз, полі(Ф)аз) у процесах синтезу компонентів клітинної стінки і позаклітинного матриксу вивчена недостатньо. Мета. Метою дослідження було вивчення ролі полі(Ф)аз PPN1 та PPX1 у процесах формування клітинної стінки та позаклітинного матриксу клітинами дріжджів. Методи. У дослідженні використовували клітини дріжджів Saccharomyces cerevisiae з відповідними делеціями ( $\Delta p p n 1$ та $\Delta p p x 1)$. Для індукції стресової реакції клітини піддавали впливу перекису водню (25-100 мМ), оцтової кислоти (25-100 мМ) та сорбітолу $(0,25-1,0 \mathrm{M})$. Радіочастотне електромагнітне випромінювання (40,68 МГц, потужність 15 Вт, експозиція $30 \mathrm{xв)} \mathrm{вивчали} \mathrm{окремо,} \mathrm{а} \mathrm{також}$ як індуктор адаптивної відповіді, для чого клітини дріжджів опромінювали РЧ ЕМВ до моменту впливу інших факторів стресу. Вплив факторів стресу оцінювали за зміною кількості цукрів. Цукрові залишки та цукри в клітинних стінках та в позаклітинному матриксі визначали за допомогою методу GC/MS та методу лектинів мічених колоїдним золотом. Оцінювали вміст $D$-манози/ $D$-глюкози (Man/Glu), $D$-галактози (Gal), $N$-ацетил- $D$ глюкозаміну (GlcNAc), $N$-ацетил- $D$-галактозаміну factors. The data obtained indicate that the activity of PPN1 and PPX1 regulates the sugar content in the cell wall and extracellular matrix and ensure the resistance of the yeast cells to stress factors.

(GalNAc) та $N$-ацетилнейрамінової кислоти (NANA). Результати. Дефектність за PPN1 та PPX1 впливає на вміст цукрів у клітинних стінках та в позаклітинному матриксі. Кількість глюкозаміну (за даними GC/MS-аналізу) зменшується у 3-5 разів у клітинних стінках клітин дефектних за PPN1 та PPX1. Метод мічених лектинів показав, що вміст Man/Glu був найбільш стабільним (27-38\%) серед всіх вивчених клітин дріжджів, тоді як кількість інших цукрів суттєво варіювала. Дефектність за полі(Ф)азами мала різний вплив на вміст цукрів в клітинних стінках та в позаклітинному матриксі: в позаклітинному матриксі відмічалося значне зниження GlcNAc, GalNAc та збільшення NANA, тоді як вміст GalNAc в клітинних стінках залишався майже постійним, а вміст NANA зменшувався при дефектності за PPN1 та збільшувався при делеції РPХ1. Проведений кореляційний аналіз показав потенційно високий (до 97\%) зв'язок між вмістом Man/Glu, GlcNAc та GalNAc у клітинних стінках із життєздатністю клітин (стійкістю до стресів). Однак серед цих цукрів лише GlcNAc виявив зв'язок із дефектністю за PPN1 та PPX1. Відмінності між ефектами, відміченими в клітинах із одиночною і подвійною делеціями генів полі(Ф)аз, вказують на те, що обидві полі(Ф)ази позитивно регулюють біосинтез GlcNAc клітинної стінки та позаклітинного матриксу та біосинтез GalNAc позаклітинного матриксу. Висновки. Обидві полі $(\Phi)$ ази (PPN1 та PPX1) беруть участь в організації будови клітинної стінки та позаклітинного матриксу і впливають, головним чином, на вміст мінорних складових: Gal, GalNAc, GlcNAc та NANA. Зміни стійкості клітин дріжджів до впливу стресових факторів, які виникають при дефектності за PPN1 та PРX1, корелюють із вмістом окремих цукрів, серед яких й GlcNAc, синтез якого регулюється функціональною активністю обох полі(Ф)аз. Встановлені відмінності та зміни у складі ПС можуть опосередковано вказувати на зменшення міцності клітинної стінки та зменшення в ній GPI-зв'язаних білків, а також на конформаційні зміни ПС в позаклітинному матриксі, які відбуваються внаслідок делеції полі(Ф)аз. 
Ключові слова: полісахариди, клітинна стінка, позаклітинний матрикс, поліфосфатази, стрес, Saccharomyces cerevisiae.

1. Lesage G, Bussey H. Cell wall assembly in Saccharomyces cerevisiae. Microbiol Mol Biol Rev. 2006; 70(2):317-43.

2. Kulaev IS, Vagabov VM, Kulakovskaya TV. The biochemistry of inorganic polyphosphates, 2nd ed. Chichester, UK: John Wiley \& Sons, Ltd. 2004, p.276.

3. Zvonarev AN, Crowley DE, Ryazanova LP, Lichko LP, Rusakova TG, Kulakovskaya TV, Dmitriev VV. Cell wall canals formed upon growth of Candida maltosa in the presence of hexadecane are associated with polyphosphates. FEMS Yeast Research. 2017; 17(3):fox026.

4. García R, Bermejo C, Grau C, Pérez R, Rodríguez-Peña JM, Francois J, Nombela $C$, Arroyo J. The global transcriptional response to transient cell wall damage in Saccharomyces cerevisiae and its regulation by the cell integrity signaling pathway. J Biol Chem. 2004; 279(15):15183-95.

5. Bru S, Martinez JM, Hernandez-Ortega S, Quandt E, Torres-Torronteras J, Marti RR, Canadell D, Arino J, Sharma S, Jimenez J, Clotet J. Polyphosphate is involved in cell cycle progression and genomic stability in Saccharomyces cerevisiae. Mol Microbiol. 2016; 101(3):367-80.

6. Kalebina TS, Egorov SN, Arbatskii NP, Bezsonov EE, Gorkovskii AA, Kulaev IS. [The role of high-molecular-weight polyphosphates in activation of glucan transferase Bgl2p from Saccharomyces cerevisiae cell wall]. Doklady Biochemistry and Biophysics. 2008; 420(1):142-45. Russian.

7. Kalebina TS, Kulaev IS. [The role of proteins in the formation of the molecular structure of the cell wall of yeast]. Adv Biol Chem. 2001; 4:105-30. Russian.
8. Voychuk SI, Gromozova OM. The functional role of PPN1 and PPX1 polyphosphatases under stresses action and for adaptive response development. Mikrobiol. Z. 2020; 82(1):3-12.

9. Pitarch A, Nombela C, Gil C. Cell wall fractionation for yeast and fungal proteomics. 2D PAGE: Sample preparation and fractionation. 2008; 217-39.

10. Dallies N, François J, Paquet V. A new method for quantitative determination of polysaccharides in the yeast cell wall. Application to the cell wall defective mutants of Saccharomyces cerevisiae. Yeast. 1998; 14:1297-1306.

11. François JM. A simple method for quantitative determination of polysaccharides in fungal cell walls. Nature Protocols. 2007; 1:29953000.

12. Pinto $M$, Coelho $E$, Nunes $A$, Brandão $T$, Coimbra MA. Valuation of brewers spent yeast polysaccharides: A structural characterization approach. Carbohydrate Polymers. 2015; 116:215-22.

13. Kulakovskaya TV, Trilisenko LV, Lichko LP, Vagabov VM, Kulaev IS. The effect of inactivation of the exo- and endopolyphosphatase genes PPXI andPPN1 on the level of different polyphosphates in the yeast Saccharomyces cerevisiae. Microbiology. 2006; 75(1):25-8.

14. Klis FM, Mol P, Hellingwerf K, Brul S. Dynamics of cell wall structure in Saccharomyces cerevisiae. FEMS Microbiology Reviews. 2002; 26(3):239- 56.

15. Soares RM, de A Soares RM, Alviano DS, Angluster J, Alviano CS, Travassos LR. Identification of sialic acids on the cell surface of Candida albicans. Biochim Biophys Acta. 2000; 1474(2):262-8.

Received 11.03.2020 